\title{
Regional Impact of Côte d'Ivoire's 1999-2000 Sociopolitical Crisis: An Assessment
}

Ousmane Doré, Benoît Anne, and Dorothy Engmann 


\title{
IMF Working Paper
}

\begin{abstract}
African Department

\section{Regional Impact of Côte d'Ivoire's 1999-2000 Sociopolitical Crisis: An Assessment}

\author{
Prepared by Ousmane Doré, Benoît Anne, and Dorothy Engmann ${ }^{3}$ \\ Authorized for distribution by Reinold van Til
}

April 2003

\begin{tabular}{l} 
Abstract \\
\begin{tabular}{|l|}
\hline The views expressed in this Working Paper are those of the author(s) and do not \\
necessarily represent those of the IMF or IMF policy. Working Papers describe \\
research in progress by the author(s) and are published to elicit comments and to \\
further debate.
\end{tabular} \\
\hline
\end{tabular}

This paper evaluates the impact of the sociopolitical crisis in Côte d'Ivoire on the economies of its neighbors. Using a nonsubjective weighted index of regional instability in crosscountry time-series regressions, it shows that the increase in regional instability caused by domestic instability in Côte d'Ivoire had a negative effect on the growth performance of its most direct neighbors, but no significant effect on the subregion as a whole including the West African Economic and Monetary Union (WAEMU). The paper also examines the channels through which such spillover effects took place.

\section{JEL Classification Numbers:B22, E13, F4, F8}

Keywords: Regional Integration, Contagion, Economic Growth, Regressions.

Authors' E-mail Addresses: odore@imf.org; banne@imf.org;D.A.A.Engmann@warwick.ac.uk

\footnotetext{
${ }^{1}$ These authors would like to thank, without implication, Elliott Harris and Paul Masson for their useful comments and suggestions.
} 


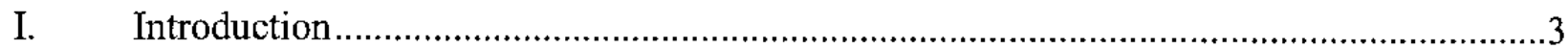

II. Modeling the Economic Impact of the Crisis in Surrounding Countries.............................5

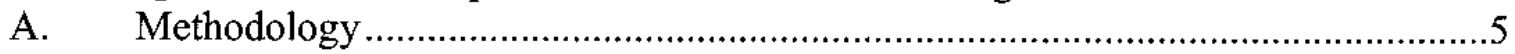

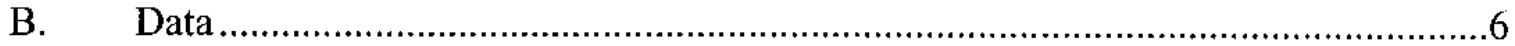

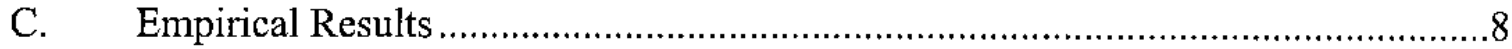

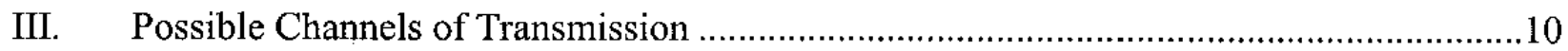

A. Impact Through Trade and Transportation ........................................................10

B. Impact Through Capital Flows and Current Transfers .......................................13

C. Impact Through Reduced Investment ............................................................

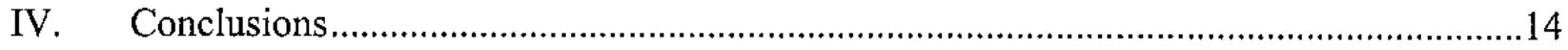

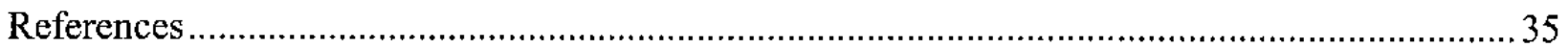

Tables

1. Selected Economic and Financial Indicators, 1994-2000 ….........................................16

2. Regional Classification: Bordering Countries ..............................................................

3. Percentage Change in Regional Instability Index: Two Scenarios ...................................18

4. Summary Statistics for All Nine Countries From 1994 to 2000 ….................................19

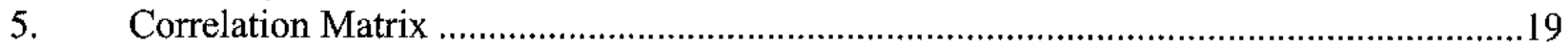

6. Regression Results (Dependent Variable: GDP Growth) …........................................23

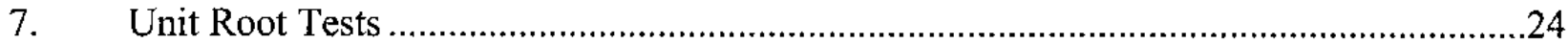

8. Autocorrelation Tests on Data Set with Actual Domestic Instability Indices

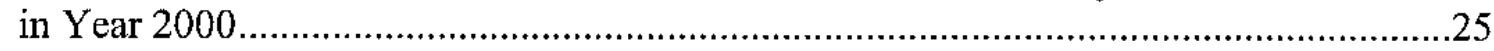

9. Regression Results (Government Expenditure Variable Differenced) ..............................26

10. Exports from Côte d'Ivoire to the Region, 1994-2000 …...............................................27

11. Imports to Côte d'Ivoire from the Region, 1994-2000 …...............................................28

12. Main Destination for Exports from Côte d'Ivoire and Neighboring Countries, 1999-2000

13. Main Origins of Imports to Côte d'Ivoire and Neighboring Countries, 1999-2000....

14. Volume of Imports and Exports of Goods to Countries in the Region, 1995-2000

15. Current Transfers of Countries in the Region, 1994-2000 …........................................32

16. Net Foreign Direct Investment of Countries in Region, 1994-2000 ................................33

17. Index of Domestic Instability in Selected West African Countries ....................................34

Figures

1. Full Sample of Nine Countries: Instability and Growth .............................................20

2. Subsample of Six WAEMU Countries: Instability and Growth ........................................

3. Subsample of Five Countries in Geographical Proximity: Instability and Growth 


\section{INTRODUCTION}

Once considered the jewel of West Africa and an oasis of political stability in a volatile neighborhood, Côte d'Ivoire found itself in the midst of a deep sociopolitical crisis, starting in 1999 with a military coup d'état. The ensuing sociopolitical events of 1999-2000 had a significant impact on the overall macroeconomic environment. After expanding by an average rate of 5.6 percent annually during the period 1994-98, the economy contracted by about 0.2 percent on average during 1999-2000 (Table 1). As a result, real GDP per capita, which had grown at an average rate of 1.8 percent in 1994-98, declined by 3.9 percent on average in the latter two years; by end-2000, real GDP per capita was actually below its 1994 level. At the same time, the ratio of gross investment to GDP, which had averaged 16 percent in 1994-98, fell to 14 percent on average in 1999-2000. Private investment declined substantially, mainly reflecting much lower private sector confidence in the context of the deteriorated sociopolitical climate. In particular, foreign direct investment dropped to CFAF 72 billion in 2000 from CFAF 183 billion three years earlier. Public investment fell to 3.1 percent of GDP in 2000 from 6.7 percent in 1998 , leaving no room for public spending to boost economic activity.

The secondary and tertiary sectors were severely affected by the sharp deterioration in the economic environment, while agriculture remained relatively sheltered from the political turmoil, given its heavy reliance on exogenous factors such as weather conditions and world commodity prices. $^{2}$ Overall, activity in the secondary sector declined on average by 4.8 percent during the period 1999-2000, in sharp contrast to the growth rate of 10 percent on annual average recorded during 1994-98. In particular, sectors such as construction and manufacturing were severely hit by the downturn, owing to the slashing of public expenditure programs, as well as the slowdown of private sector activity. The industrial production index fell by about 7.8 percent in 2000 after it had risen steadily since 1994 . Activity in the tertiary sector contracted by almost 3 percent on average in 1999-2000, compared with an expansion of 4.2 percent during 1994-98. Key sectors, such as commerce and transport, experienced no growth during the period, while activity in the Port Autonome d'Abidjan (PAA), the busiest port in francophone West Africa and one that handles much of the business of its landlocked neighbors (Burkina Faso and Mali), fell by an estimated 8 percent.

On the fiscal front, the cash-flow situation of the treasury deteriorated, mainly as a result of weaker revenue collection. The fall in revenue to a large extent reflected the economic

\footnotetext{
${ }^{2}$ Nonetheless, the ethnic troubles associated with the worsening political climate put some pressure on the labor supply in the coffee and cocoa growing areas, especially in the western and southern parts of the country. It is reported that, in the aftermath of the coup, 12,000 migrant agricultural workers had to leave Tabou (in the south) because of ethnic clashes with the indigenous Krou population. This movement would inevitably have affected yields and productivity of cocoa and coffee plantations.
} 
slowdown, increasing tax exemptions, fraud, and weaker tax compliance. The significant dwindling of external financial assistance further complicated the treasury's cash-flow situation, which, in turn, led to a large accumulation of domestic and external arrears. This accumulation of government arrears contributed to a further eroding of private sector confidence, a worsening of Côte d'Ivoire's relations with its external partners, and a weakening of the situation of the financial system. On the structural front, the reform process in key structural areas came to a halt, including the reform of the public financial sector and privatization in the energy sector, as the authorities were mostly preoccupied with the political agenda. The crisis contributed to a deterioration in the living standards in Côte d'Ivoire and increased poverty, as the many investment projects in the social sectors did not materialize owing to cuts in public investment. While little current statistical data exist on poverty indicators, the budget allocations for health and education were lower in 1999-2000 than in preceding years.

As an important trading partner for its neighbors, and an important port of entry and exit for their imports and exports, Côte d'Ivoire's economic crisis had some spillover effects on the economies of neighboring countries. However, the channels of transmission and the extent of the impact were different from country to country, depending on the size and the geographical proximity of the countries. The economies of West African countries as a whole experienced an economic slowdown during 1999-2001 whose timing and severity could in part be associated with the Ivoirien crisis. Growth in the West African Economic and Monetary Union (WAEMU) decelerated to a modest $2 \frac{1}{2}$ percent on average during 1999-2000, compared with about 5 percent during the post-devaluation period (1994-98). Other countries (e.g., Ghana and Guinea) also experienced slower growth than the average growth rate of the preceding years.

This paper attempts to evaluate the impact of the recent sociopolitical crisis in Côte d'Ivoire on the economies of its neighbors. It uses cross-country time-series regressions of economic growth for a group of countries that are geographically and economically linked to Côte d'Ivoire to establish whether an increase in political instability in Côte d'Ivoire contributed to unfavorable growth performance in the rest of the region. It also investigates the extent to which countries in close geographical proximity to Côte d'Ivoire, such as Burkina Faso, Ghana, Guinea, and Mali, were hurt more than other countries further away, such as Senegal. While somewhat related to an emerging literature on the impact of regional political instability on economic performance, this study is unique in its use of an estimated nonsubjective, weighted index of regional instability based on statistics calculated by the Political Risk Services (PRS) Group to explain regional growth performance in a cross-country time-series regressions model.

Section II provides an empirical assessment of the impact of the crisis on the neighboring countries, followed by an examination of the channels of transmission of the crisis in Section III. Section IV concludes. 


\section{Modeling The ECONOMIC IMPACT OF THE CRISIS IN SURROUNding CoUNTRIES}

\section{A. Methodology}

This study utilizes the idea put forward by Ades and Chua (1993) that regional instability has a negative impact on the economic growth of neighboring countries. The methodology used to capture the impact of political instability in Côte d'Ivoire on the economic growth of its neighbors is a cross-section time-series regression of economic growth on domestic instability and regional instability variables using a small sample of countries (nine) over a short period of time (1994-2001). There are some benefits of using cross-country regressions, including the fact that they can be viewed as evaluating the strength of partial correlations between economic growth and policy indicators. Indeed, when cross-country regressions are used with other analytical methods, they demonstrate that certain policy indicators influence growth across countries.

In order to examine the possibility of different effects on different countries, regressions will be run first on the full sample of nine countries, and then on two subsamples of countries: one subsample containing WAEMU countries only and the other subsample containing Côte d'Ivoire and its four geographical neighbors (Burkina Faso, Ghana, Guinea, and Mali). To capture fixed effects, the panel data model to be estimated allows the intercept to vary across countries. This allows us to test whether there are individual differences across countries modeled as parametric shifts in the regression function. The basic individual effects model is given by the following:

$$
y_{i t}=\alpha_{i}+\underline{X}^{\prime}{ }_{i t} \underline{\beta}_{i t}+\mu_{i t}
$$

where $y_{i t}$ is GDP growth for country $i$ at time $t, X^{\prime}{ }_{i t}$ is a $(1 \times K)$ row vector of explanatory variables, $\underline{\beta}_{i t}$ is a $(K \times 1)$ column vector of (unknown) regression coefficients, and $\alpha_{i}$ is the intercept for individual $i$. Thus for full sample of $N$ countries over $T$ time periods, the model is given by:

$$
\underline{y}=D_{N} \underline{\alpha}+\tilde{X} \tilde{\beta}+\underline{\mu}
$$

where $\underline{y}$ is a $(N T \times 1)$ column vector of the dependent variable, $D_{N}$ is a $(N T \times N)$ matrix containing a set of $N$ individual dummy variables, $\alpha$ is a $(N \times 1)$ vector of intercepts, $\widetilde{X}$ is a $(N T \times(K-1))$ matrix of explanatory variables, $\underline{\tilde{\beta}}$ is a $(K-1)$ column vector of slope parameters, and $\underline{\mu}$ is a $(N T \times 1)$ column vector of the random terms.

The dependent variable in the regression is GDP growth per year. The explanatory variables include a domestic instability index, a regional instability index, and terms of trade, government expenditure, and devaluation dummy variables. Domestic instability is widely accepted as a 
significant determinant of economic growth (see, for example, Barro (1989); Alesina and others (1992); Alesina and Perotti (1993); and Guillaumont, Jeanneney and Brun (1999)), although there is much debate about the direction of causality from domestic political instability to economic growth. Political instability disrupts economic activity and diverts resources from more productive uses to military and other less economically productive sources. Political uncertainty also has adverse effects on property rights, and this affects private investment which, in turn, has an impact on economic growth. Some authors have also found that instability in neighboring countries has a detrimental impact on the economic growth of a country (for example, Ades and Chua, 1993). Terms of trade are also known as an important source of shocks, especially for countries whose exports are primary commodities (Masson and Pattillo, 2001). The government expenditure variable has been also related to growth through its crowding-out effect on private investment (Barro, 1989), although in some cases too little government expenditure (for example, in infrastructure) inhibits private investment.

\section{B. Data}

Annual data over a seven year period from 1994 to 2000 will be used for this analysis. There will be nine countries in the sample: Burkina Faso, Côte d'Ivoire, Ghana, Guinea, GuineaBissau, Mali, Niger, Senegal, and Togo. ${ }^{3}$ Using a pooled sample of cross-section time-series data gives us 63 observations (nine countries over seven years). The panel data approach allows the use of a larger number of observations and may help identify effects that cannot be identified by using purely cross-section or time-series data. Data on GDP growth rates, terms of trade, and government expenditure are taken from the International Monetary Fund World Economic Outlook database.

To estimate the domestic instability variable, a domestic instability index has been calculated based on the PRS Group's estimates of risk indices regarding the political, financial, and economic situation in a country. ${ }^{4}$ The PRS Group reports the indices monthly, and thus an annual average of the indices has to be calculated as:

${ }^{3}$ Benin is excluded from the empirical analysis because of a lack of data on domestic political instability, and Liberia is excluded as a sample country because it lacks data on macroeconomic aggregates. However, Liberia's domestic instability index is used in calculating the regional instability indices of Côte d'Ivoire and Guinea -two of its geographical neighbors.

${ }^{4}$ The PRS Group has been providing businesses with data on political, financial, economic, and the combined risks of investing/participating in countries for over 20 years. The risk indices $(100=$ best, $0=$ worst) are computed monthly. The publication, $A$ Brief Guide to the Ratings System, by the International Country Risk Guide provides an excellent discussion of how the indices are calculated. 


$$
D I I_{i}=\frac{1}{m} \sum_{1}^{m} \text { political risk index, }
$$

where $m$ is the number of months in a year for which data are available. This method of estimating the domestic instability index is unique. Previous studies have estimated the index based on the number of coups, assassinations and assassination attempts, riots, and other forms of domestic instabilities. The data used in such studies are thus subjective and difficult to reproduce.

The year-on-year percentage improvement in the index will be calculated and included in the regression. The coefficient on this variable is expected to be positive: an improvement in the domestic instability index has a positive impact on economic growth.

A regional instability index has also been estimated using the following formula:

$$
\begin{aligned}
& R I=\text { regional instability index } \\
& R I I=\frac{1}{n} \sum_{1}^{n} D I, \text { and } \\
& D I I=D I I_{i} \times \frac{G D P_{i}}{G D P_{\text {Total }}},
\end{aligned}
$$

where $n$ is the number of neighboring countries bordering the country concerned, ${ }^{5} i$ denotes the bordering country under consideration, $D I I$ is the weighted index of political instability, $G D P_{i}$ is the Gross Domestic Product in country i, $G D P_{\text {Total }}$ is the total GDP of neighboring countries. To show whether an increase in domestic instability in Côte d'Ivoire has contributed to an increase in regional instability, two sets of regional instability indices will be computed for the nine countries for the year 2000 . The first one shows the percentage change in each country's

\footnotetext{
${ }^{5}$ We define "neighboring countries" to be countries in geographical proximity to a country and that are members of Economic Community Of West African States (ECOWAS) or WAEMU (Table 2). This allows us to exclude countries like Algeria and Libya, which are Niger's and Mali's geographical neighbors but whose large GDPs heavily bias the measure of regional instability: this is out of proportion to the degree of economic cooperation between countries in North and West Africa.
} 
regional instability index in 2000 if Côte d'Ivoire's domestic instability index did not change from its 1999 level. ${ }^{6}$ The second shows the actual percentage change in each country's regional instability index using Côte d'Ivoire's domestic instability index for the year 2000. These results are summarized in Table 3. As shown, if it is assumed that Côte d'Ivoire's index of domestic instability did not fall in the year 2000, the regional instability index of countries in close geographical proximity to Côte d'Ivoire would have improved by an average of 0.43 percent. The index declines by an average of 15.7 percent when the actual 2000 domestic instability index for Côte d'Ivoire is used.

\section{Empirical Results}

Table 4 provides summary statistics of the indices of domestic and regional instability, and Table 5 reports on the correlation of the variables to be included in the growth regression. There is a low positive correlation between the domestic instability index and the regional instability index. This low correlation implies that there is information embodied in the regional instability index that is not captured by the domestic instability index. In addition, the low correlation suggests that regional instability can be treated as independent of the domestic instability rather than the consequence of domestic instability spilling over into neighboring countries. There is also a low correlation between the domestic instability index and GDP growth which helps dispel any queries one might have about the endogeneity of the domestic instability variable.

Figures 1,2, and 3 plot the relationship between domestic instability and economic growth, and between regional instability and economic growth, for the three samples of countries under consideration. For the full sample of nine countries, there appears to be a small positive relationship between an improvement in domestic and regional instability and economic growth. For the subsample of six WAEMU countries, the positive relationship is more pronounced for domestic instability and economic growth, and less so for regional instability and economic growth. In Figure 3, the positive relationships are more pronounced for the subsample of five countries in geographical proximity to each other-there is a clear positive relationship between domestic instability and economic growth, and between regional instability and economic growth.

Table 6 summarizes the importance of instability indices as a prediction of economic growth in three groups of countries: the full sample of nine countries; a subsample of six WAEMU countries, ${ }^{7}$ and a subsample of five countries - Côte d'Ivoire, together with its four geographical

${ }^{6}$ This assumption is fairly realistic as Côte d'Ivoire's coup d'état did not take place until December 24, 1999, with subsequent looting, riots and clashes between rival protestors. Its 1999 index of domestic instability will therefore reflect only events prior to this, when Cote d'Ivoire was still regarded as a peaceful and successful country.

${ }^{7}$ Guinea-Bissau is left out of the analysis at this point because it only joined the WAEMU in 1997. 
neighbors (Burkina Faso, Ghana, Guinea, and Mali). The regressions on the full sample of nine countries and on the subsample of six WAEMU countries using the two different regional instability indices have small coefficients of determination $\left(R^{2}\right)$ and large residual variances $\left(\delta^{2}\right)$. The coefficient on the domestic instability index is positive and significant in all cases, while the coefficient on the regional instability index is insignificant in all cases. That is, an improvement in domestic instability is associated with an improvement in economic growth, but an improvement in regional instability does not seem to be associated with greater economic growth.

The regional instability index is not significant in these two samples of countries for several reasons. First, it can be said that regional instability was not an important factor in economic growth during 1994-2000. Second, regional instability did have a negative impact on neighboring countries, but was not significant enough to show up in economic growth figures. Thus, the effect may have been restricted to one sector only (such as cross-border investment), and this was compensated for by above-average performance in other sectors. Third, countries had in place sound macroeconomic policies that withstood the impact of instability in neighboring countries. Fourth, a lot of the business of these countries is conducted with countries outside the region, most notably in Europe (especially France). Fifth, positive exogenous factors, such as foreign aid flows, may have offset the possible negative effects of regional instability. Sixth, with the exception of the three landlocked countries in the sample, all the countries have seaports and as such may not be affected by trade disruptions, a major channel of the negative impacts of domestic political crises to neighboring countries.

Running the same regressions for a subsample of five countries (Côte d'Ivoire and the four countries in direct proximity to it), we find a much larger coefficient of determination (with $R^{2}=$ 0.65 on average) and a small residual variance $\left(\delta^{2}=1.85\right.$ on average). We also find that the regional instability index is insignificant when Cote d'Ivoire's index of domestic instability is kept at its 1999 level in the year 2000, but turns significant (at the 10 percent) level when Côte d'Ivoire's actual index in 2000 is used in the calculation. Therefore, it can be inferred that, ceteris paribus, if Côte d'Ivoire's political stability had remained the same in the year 2000 as in 1999, the downturn in economic growth in neighboring countries could not have been explained by a worsening of regional instability. Our result suggests that the sharp decline in Côte d'Ivoire's political stability in 2000 was instrumental in increasing the regional instability experienced by its geographical neighbors, and that this instability negatively affected economic growth in these countries (Burkina Faso, Ghana, Guinea, and Mali).

There are a number of reasons why regional instability is significant for the subsample of five countries, but not for the subsample of WAEMU countries or the sample of all nine countries. First, trade disruptions were more significant for the five countries in the sample, either through intraregional trade flows (Côte d'Ivoire is the main regional source of imports for Burkina Faso, Guinea, and Mali) or through disruption of transportation to the coast for the landlocked countries in the sample (Burkina Faso and Mali). Second, private worker remittances from economic migrants in Côte d'Ivoire to Burkina Faso, Ghana, Guinea, and Mali formed a significant part of the current transfer balance of these countries. These transfers, particularly to 
Burkina Faso and Mali, are a significant source of foreign exchange, and represent a significant proportion of household income in rural areas. The repatriation of these migrants, or fewer economic opportunities for the migrants who stayed in Côte d'Ivoire during 1994-2000, therefore negatively affected neighboring countries. Third, there may have been a fall in crossborder investment that significantly affected these economies. Fourth, an increase in defensive military expenditures (for example, in Guinea and Mali) as a consequence of instability in neighboring countries diverted resources from more productive economic activities.

We can go further by suggesting that in this sample of five countries, an improvement in regional stability of 1 percent is associated with an increase in economic growth of about six percent. ${ }^{8}$ This effect is not negligible when compared with the estimated impact of an improvement in domestic stability: a 1 percent increase in domestic stability is associated with a 17 percent increase in economic growth. $^{9}$

\section{Possible Channels of Transmission}

The possible channels through which the Ivoirien crisis had an impact on the economic performance of the countries in direct geographical proximity to Côte d'Ivoire include trade linkages, current transfers, and investment.

\section{A. Impact Through Trade and Transportation}

An important channel through which the crisis in Côte d'Ivoire can affect neighboring economies is trade and transport links. ${ }^{10}$ While intraregional trade in West Africa is low in comparison to world regional trade figures, it is still an important source of revenue and goods for the countries; thus, an economic downturn Côte d'Ivoire, which weakens both the volume of imports and exports in the region, would affect these economies.

As shown in Tables 10 and 11, the growth of exports from Côte d'Ivoire to three of the four geographical neighbors (Burkina Faso, Ghana, and Mali) fell in 1999-2000, compared with

\footnotetext{
${ }^{8}$ As we have not estimated a structural model, our coefficients cannot explicitly be interpreted as elasticities. However, coefficient estimates can be used to evaluate the strength of the partial correlation between growth and the independent variables in our equation.

${ }^{9}$ Compared with significant increases in economic growth of 18 percent and 21 percent in the sample of nine countries and the subsample of WAEMU countries, respectively, when domestic stability is improved by 1 percent.

${ }^{10}$ This is one of the channels through which the impact of the Asian economic crisis spread. Nixson and Walters (1999) show that the Asian crisis had a significant impact of the volume and prices of traded goods, and that those countries heavily dependent on intraregional trade were the most affected.
} 
1994-98. The growth of imports from three of the countries (Burkina Faso, Ghana, and Guinea) to Côte d'Ivoire also fell in 1999-2000 from the 1994-98 levels. However, the extent to which the fall in imports and exports has a negative impact on the economic growth of these countries, depends on the extent to which the countries depend on Côte d'Ivoire as a significant source of imports/exports. Table 12 shows the main destination of exports from the countries in the region and the shares of exports from these countries to Côte d'Ivoire in the value of total trade of the countries. Between 1999 and 2000, the share of exports to Côte d'Ivoire from Ghana and Guinea fell. Even if these countries found alternative markets for their goods, there would still have been associated search costs. However, these shares represented small proportions of the total value of trade conducted by these countries, and as such the impact of the lost export markets and search costs would be minimized. Table 13 shows the main origins of imports for the countries in 1999 and 2000, and the share of imports from Côte d'Ivoire to the countries in the value of total trade of the countries. Côte d'Ivoire is the main regional source of imports for Burkina Faso, Guinea, and Mali, and the main source of imports for Burkina Faso worldwide. Trade disruptions would therefore, significantly affect these economies. Côte d'Ivoire saw its share of imports to Burkina Faso ${ }^{11}$ and Mali fall in 2000.

Overall, the rate of growth of exports from Côte d'Ivoire to seven of the ten countries in the region fell in 1999-2000 compared with 1994-98 (Table 10). In addition to the countries mentioned above, exports fell to Benin, Liberia, Niger, and Togo in 1999-2000. The rate of growth of imports to Côte d'Ivoire from these countries fell in eight out of ten cases in 19992000, compared with 1994-98 (Table 11). Countries with lower imports included Benin, Guinea-Bissau, Liberia, Senegal, and Togo.

Most of the ten countries in the region export primary commodities to developed and emerging countries and these groups account for the bulk of their exports. In 1999, the share of exports to Côte d'Ivoire as a percentage of the total ranged from 3.4 percent in Senegal to 0.1 percent in Burkina Faso (Table 12). However, like imports, these shares declined in 2000 in seven countries including Benin, Guinea-Bissau, Niger, and Senegal. In 2000 the share of exports to Côte d'Ivoire ranged from 1.7 percent in Senegal to 0 percent in Niger (worth about US\$3.7 million to Senegal). Even if countries such as Senegal found alternative markets for their goods, there would still have been associated search costs. Côte d'Ivoire is also the main regional source of imports for Niger and Senegal. Côte d'Ivoire saw its share of imports fall in seven of the countries, including Benin, Guinea-Bissau, Mali, and Niger (Table 13).

Transportation routes are another important channel of spillover effects of crisis. ${ }^{12}$ The landlocked countries of Mali, Burkina Faso, and even Niger use transportation routes through

${ }^{11}$ France marginally took over as the main source of imports for Burkina Faso in 2000.

12 Ades and Chua (1993) cite Malawi and Rwanda as landlocked countries that have been affected by political turmoil in Mozambique and Uganda, respectively, through transportation routes that were either destroyed or blocked. 
Côte d'Ivoire to reach the seaport, from where they can import and export goods. Indeed, the Port Autonome d'Abidjan (PAA) in Côte d'Ivoire is the busiest port in francophone West Africa and handles much of the business of its landlocked neighbors (Burkina Faso and Mali). Petroleum products alone account for about 40 percent of the tonnage handled in the port. The political and economic crisis of 1999 and 2000 reduced the total traffic at the PAA by an estimated 8 percent. ${ }^{13}$ The current political problems in Côte d'Ivoire have led to the installation of regular police checkpoints along the main routes used by these countries, which have therefore started shipping through other countries, such as Togo, in an attempt to avoid the inconvenience. A recent reports suggests that Côte d'Ivoire lost about 50 percent of its road business as its landlocked neighbors switched to ports in Benin, Ghana, Senegal, and Togo to avoid the multitude of police checkpoints along roads. ${ }^{14} 15 \mathrm{In}$ addition, actual and potential political instability implies that the routes are unsafe and cannot be relied on to be open and used at all times.

There is a large amount of informal trade between the countries in the region. As such, it is difficult to obtain exact data on the degree to which the crisis in Cote d'Ivoire affected the transportation of goods between neighboring countries. However, inferences can be drawn by examining the volume of imports and exports for a sample of countries. Table 14 shows the volume of imports to, and exports of goods from Burkina Faso, Mali, and Côte d'Ivoire between 1994 and 2000 (countries that were most likely to have experienced a decline in the volume of trading), and also to Benin, Ghana, Senegal, and Togo for the same period (countries that were most likely to have benefited from an increase in volume of trade as a consequence of the crisis in Cote d'Ivoire). ${ }^{16}$ The volume of imports of goods fell in 2000 compared with 1999 to Burkina Faso, Cote d'Ivoire, and Mali, and also in Ghana and Senegal. The volume of imports to Benin and Togo rose. In addition, the volume of exports of goods fell from Burkina Faso, Côte d'Ivoire, Mali, and Senegal, but rose from Benin, Ghana, and Togo. Thus it appears that only Benin and Togo experienced a rise in both imports and exports. It is possible that these countries benefited from the crisis in Côte d'Ivoire by an increased use of transportation routes through these countries. However, to the extent that Benin and Togo were used as trade routes, this channel of transmission is not believed to have been significant to the landlocked countries,

${ }^{13}$ Economist Intelligence Unit, 2001.

14 "Road Shipments Through Ivory Coast down 50\%," Dow Jones International News Service, July 26, 2001. This figure reflects road transport, including, but not limited to, transshipment of goods.

${ }^{15}$ This is an example of how Benin, Ghana, Senegal, and Togo may have benefited from political instability in Côte d'Ivoire

${ }^{16}$ The data reflect imports/exports of all goods, not just Ivoirien goods. 
as the effect would mostly have been through higher intermediate costs and/or slower delivery. $^{17}$

\section{B. Impact Through Capital Flows and Current Transfers}

The spillover effect of the Ivoirien crisis on neighboring countries could also take place through capital flows and current transfers. ${ }^{18}$ Private current transfers, mostly repatriated earnings or private worker remittances, account for a significant share of the current transfer part of each country's balance of payments. In 1999 in Burkina Faso, such remittances amounted to US\$79 million, a significant source of foreign earnings when compared with the US\$141 million earned that year from cotton exports. Table 15 shows current transfers to countries in the region during the period 1994-2000. Current transfers to Burkina Faso, Guinea, Mali, and Niger fell in 2000. These were the exact countries that were identified as most likely to have experienced a decline in current transfers as a consequence of the crisis in Côte d'Ivoire. In Burkina Faso, workers' remittances fell from CFAF 50.3 billion to CFAF 41.0 billion, mainly as a consequence of repatriation of economic migrants from Côte d'Ivoire and the worsening economic situation in that country. Data on worker remittances to Guinea, Mali, and Niger are not well recorded. ${ }^{19}$

\section{Impact Through Reduced Investment}

Political instability in sub-Saharan Africa is likely to result in a reduction in private foreign investment in neighboring countries, especially where as in the WAEMU, there is a high degree of economic and financial integration between the economies. A fall in investment dampens aggregate demand and growth potential. Neighboring countries may also increase investment in the military in order to prevent the conflict from spreading to their countries and to control the influx of refugees. These resources are redirected from more productive economic and social activities, and this might have a negative impact on growth and investment. However, it is also

\footnotetext{
${ }^{17}$ More significant would have been the inability of landlocked countries to import and/or export goods.
}

${ }^{18}$ The Asian crisis in 1997-98 was characterized by massive capital outflows and falling growth rates. Indeed, contagion was spread quickly as billions of dollars of short-term capital flowed out of economies that were deemed to have similar financial and macroeconomic weaknesses as the troubled country. Private capital flows to West Africa are not of the same scale as they are to Asian countries and not believed to be an important channel of contagion.

${ }^{19}$ There is no reliable source of data on how many economic migrants returned to their homes following the crisis in Côte d'Ivoire. However, it is believed that a significant number of them did so, particularly those from the north or Muslims, at whom the verbal and physical abuse seemed to be primarily directed. 
possible for neighboring countries to benefit from instability in a country when the pool of investment that the countries are competing for is small.

Table 16 shows the net foreign direct investment in the countries in the region between 1994 and 2000. In 2000, net foreign direct investment fell in Benin, Côte d'Ivoire, and Senegal, and remained unchanged between 1999 and 2000 for Burkina Faso, Guinea, Guinea-Bissau, and Togo. Net foreign direct investment flowed in to Mali (about US $\$ 150$ million) in the second half of 2000 , mainly owing to a surge in net foreign assets of commercial banks. The financing of the current account deficit by project loans and grants, as well as by large private capital inflows related to gold-mining activity, allowed a significant accumulation of net foreign assets at the central bank. Niger recorded a relatively small increase in net foreign direct investment of about US\$2.64 million. Ghana was the only other country to record a rise in net foreign direct investment, a surprising outcome, given the uncertainty surrounding the elections in late 2000 . However, it is difficult to isolate the investment that flowed into Niger, Mali, and Ghana purely as a consequence of good economic opportunities, rather than as a consequence of less investment in Côte d'Ivoire. Of these countries it is more likely that Ghana and Niger benefited from the crisis in Côte d'Ivoire-in Mali's case because the economic opportunities afforded by a gold boom would attract investment irrespective of the political situation in Côte d'Ivoire.

A political crisis in a country may force its neighbors to increase investment/expenditures in the military to prevent the conflict from spreading to their countries and to control the influx of refugees. As resources are redirected from more productive activities, this might have a negative impact on growth and investment. In Mali, the authorities purchased military equipment in 2000 (worth CFAF 8 billion), and there was increased defense spending in Guinea. ${ }^{20}$ In Burkina Faso, the salaries of military personnel were increased by 5.3 percent in 1999 and 2.8 percent in 2000 . Military investments increased by 52.6 percent in 1999 in that country, and purchases of goods and services rose by 10.3 percent in 1999 and 4.7 percent in $2000 .^{21}$

\section{Conclusions}

This paper has argued and shown that the recent weakness in the growth performance of some countries in the West African subregion can be partly explained by the political instability in Côte d'Ivoire- the second largest economy in the zone. The effect of the Ivoirien sociopolitical crisis is shown to have been quantitatively important for countries that are geographically in proximity to Côte d'Ivoire (Mali, Burkina Faso, Guinea and Ghana): an improvement in regional stability of 1 percent is associated with an increase in economic growth of about 6 percent. However, such effects were found to be statistically insignificant for other countries taken as a group.

${ }^{20}$ Political instability from neighboring Liberia spilled over into Guinea in late 2000.

${ }^{21}$ Data provided by Burkinabè authorities. 
We find that there are three main channels through which regional instability, driven by domestic instability in Côte d'Ivoire, affects growth. First, regional instability disrupts trade flows. While intraregional trade in the region is relatively low, there is a high degree of informal and unrecorded trade between the countries, and some countries (e.g., Burkina Faso and Mali) rely heavily on the PAA and transport routes through Côte d'Ivoire to conduct a great share of their international trade. Second, political instability in Côte d'lvoire, through its impact on the Ivoirien economy, could dampen income in countries that receive a larger share of private remittances from Côte d'Ivoire. Third, political instability in the region is likely to reduce private foreign investment, which dampens the growth prospect.

The results presented in this paper provide strong evidence that there is systemic contagion across borders in Africa, as unfavorable performance in a big country (in this case, Côte d'Ivoire) tends to influence economic growth in surrounding countries. This evidence suggests that instability in neighboring countries in close geographical proximity should be treated as a negative exogenous shock to the economy, and that efforts must be taken to minimize the contagion effect. This evidence also implies that as policy choices could also be contagious across borders, economic integration within the region and macroeconomic policy coordination are viable avenues for the West African countries. 
Table 1. Selected Economic and Financial Indicators, 1994-2000

\begin{tabular}{|c|c|c|c|c|c|c|c|c|c|}
\hline & 1994 & 1995 & 1996 & 1997 & 1998 & 1999 & 2000 & $\begin{array}{r}\text { 1994-98 } \\
\text { Annual } \\
\text { average }\end{array}$ & $\begin{array}{r}1999-2000 \\
\text { Annual } \\
\text { average }\end{array}$ \\
\hline $\begin{array}{l}\text { Real GDP growth } \\
\text { (percent) }\end{array}$ & 2.0 & 7.1 & 6.9 & 6.2 & 5.8 & 1.6 & -2.3 & 5.6 & -0.2 \\
\hline $\begin{array}{l}\text { Real GDP per capita } \\
\text { (1990 US\$) }\end{array}$ & 886.3 & 914.3 & 943.4 & 966.7 & 987.3 & 967.8 & 912.5 & 939.6 & 940.1 \\
\hline $\begin{array}{l}\text { Real GDP per capita } \\
\text { growth } \\
\text { (percent) }\end{array}$ & -1.9 & 3.2 & 3.2 & 2.5 & 2.1 & -2.0 & -5.7 & 1.8 & -3.9 \\
\hline $\begin{array}{l}\text { Inflation (percent } \\
\text { change) }\end{array}$ & 26 & 14.3 & 2.7 & 4.2 & 4.5 & 0.7 & 2.5 & 10.3 & 1.6 \\
\hline $\begin{array}{l}\text { Gross investment } \\
\text { (percent of GDP) }\end{array}$ & 13.8 & 16.4 & 15.6 & 15.8 & 16.4 & 16.0 & 12.3 & 15.6 & 15.1 \\
\hline $\begin{array}{l}\text { Direct investment } \\
\text { (net, billions US\$) }\end{array}$ & 0.10 & 1.04 & 0.8 & 0.5 & 0.5 & 0.2 & 0.4 & 0.4 & 0.3 \\
\hline $\begin{array}{l}\text { Direct investment in } \\
\text { reporting economy } \\
\text { (billions US\$) }\end{array}$ & 0.10 & 0.41 & 0.4 & 0.4 & 0.4 & 0.3 & 0.3 & 0.2 & 0.2 \\
\hline $\begin{array}{l}\text { Domestic saving } \\
\text { (percent of GDP) }\end{array}$ & 26.3 & 24.5 & 23.2 & 22.3 & 22.7 & 22.8 & 18.7 & 23.8 & 21.9 \\
\hline
\end{tabular}

Sources: IMF African Department database, September 2001; and IMF World Economic Outlook database, July 2001. 
Table 2. Region Classification: Bordering Countries

\begin{tabular}{ll}
\hline Country in Sample & Bordering Countries \\
\hline Burkina Faso & (Benin), Côte d'Ivoire, Ghana, Mali, Niger, Togo \\
Côte d'Ivoire & Burkina Faso, Ghana, Guinea, Liberia, Mali, \\
Ghana & Burkina Faso, Côte d'Ivoire, Togo \\
Guinea & $\begin{array}{l}\text { Côte d'Ivoire, Guinea-Bissau, Liberia, Mali, Sierra Leone, } \\
\text { Senegal }\end{array}$ \\
Guinea-Bissau & Guinea, Senegal \\
Mali & (Algeria), Burkina Faso, Côte d'Ivoire, Guinea, (Mauritania), Niger, \\
& $\begin{array}{l}\text { Senegal } \\
\text { Niger }\end{array}$ \\
Togo & (Algeria), (Benin), Burkina Faso, (Chad), (Libya), Mali, Nigeria \\
Senegal & The Gambia, Guinea, Guinea-Bissau, Mali, (Mauritania) \\
\hline
\end{tabular}

Countries in parentheses are either not members of WAEMU or ECOWAS or data are unavailable

${ }^{22}$ The countries included in the sample are WAEMU countries, plus ECOWAS countries which border Côte d'Ivoire. Liberia and Benin have been omitted from the analysis because of a lack of data. 
Table 3. Percentage Change in Regional Instability Index: Two Scenarios

\begin{tabular}{|c|c|c|c|}
\hline & (1) & (2) & \multirow{6}{*}{$\begin{array}{l}\text { Impact of crisis in } \\
\text { Côte d'Ivoire on } \\
\text { Regional Instability } \\
\text { for Country } i \text {. }\end{array}$} \\
\hline & Regional Instability Index & Regional Instability Index & \\
\hline & for Country $i$ : & for Country $i$ : & \\
\hline & (Percent change in index) & (Percent change in index) & \\
\hline & Côte d'Ivoire DII in 2000 & Côte d'Ivoire Actual DII in & \\
\hline & Is Same as 1999 Levels & 2000 & \\
\hline Burkina Faso & -0.55 & -13.55 & -13.00 \\
\hline Côte d'Ivoire & -2.77 & -2.77 & 0.00 \\
\hline Ghana & -0.02 & -19.53 & -19.51 \\
\hline Guinea & 1.26 & -13.52 & -14.78 \\
\hline Guinea-Bissau & -0.73 & -0.73 & 0.00 \\
\hline Mali & -0.26 & -15.71 & -15.45 \\
\hline Niger & -0.39 & -0.39 & 0.00 \\
\hline Senegal & -1.73 & -1.73 & 0.00 \\
\hline Togo & -3.48 & -3.48 & 0.00 \\
\hline
\end{tabular}


Table 4. Summary Statistics for All Nine Countries from 1994 to 2000

\begin{tabular}{|c|c|c|c|c|c|}
\hline Variable & & \multicolumn{2}{|l|}{ Mean } & \multicolumn{2}{|c|}{ Standard Deviation } \\
\hline$D I I$ & & \multicolumn{2}{|l|}{2.3156} & \multicolumn{2}{|l|}{6.2160} \\
\hline$R I I$ & & \multicolumn{2}{|l|}{0.052126} & \multicolumn{2}{|l|}{5.3018} \\
\hline \multirow{2}{*}{\multicolumn{6}{|c|}{$\begin{array}{l}D I I \text { is the percentage improvement in the domestic instability index in each year. } R I I \text { is the percentage im } \\
\text { in the regional instability index in each year. }\end{array}$}} \\
\hline & & & & & \\
\hline & $G D P g$ & Govt Exp & TOT & $D I I$ & $R I I$ \\
\hline$G D P g$ & 1.0000 & & & & \\
\hline Govt Exp & 0.087600 & 1.0000 & & & \\
\hline$T O T$ & 0.17353 & 0.19586 & 1.0000 & & \\
\hline$D I I$ & 0.24375 & -0.12490 & 0.068725 & 1.0000 & \\
\hline RII & 0.043317 & 0.065495 & 0.26360 & 0.20785 & 1.0000 \\
\hline
\end{tabular}

$G D P g$ is the GDP growth rate per annum. Govt Exp is government expenditure per annum as a percentage of GDP. TOT denotes the percentage improvement in the terms of trade per annum 
Figure 1. Full Sample of Nine Countries: Instability and Growth

GDP Growth and Domestic Instability

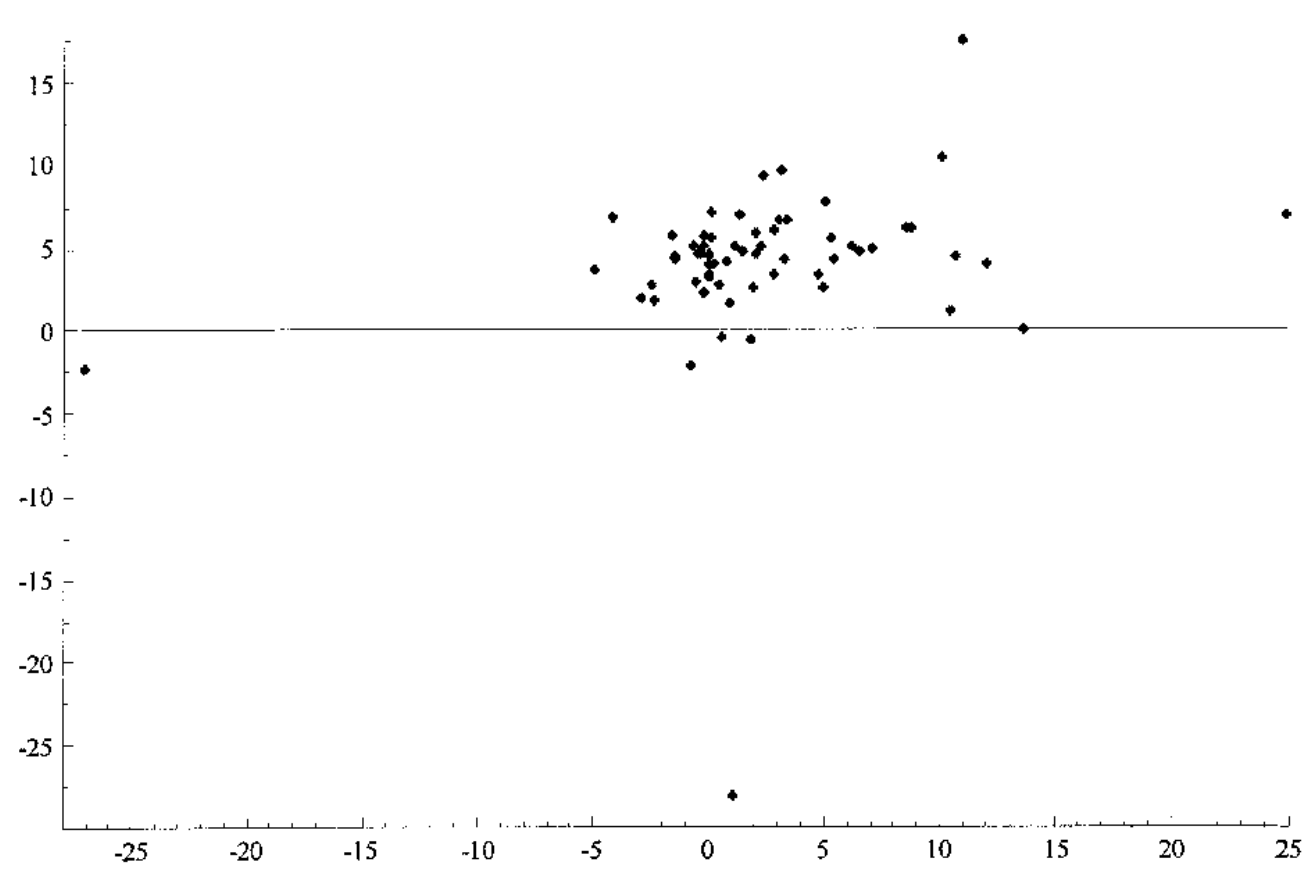

GDP Growth and Regional Instability

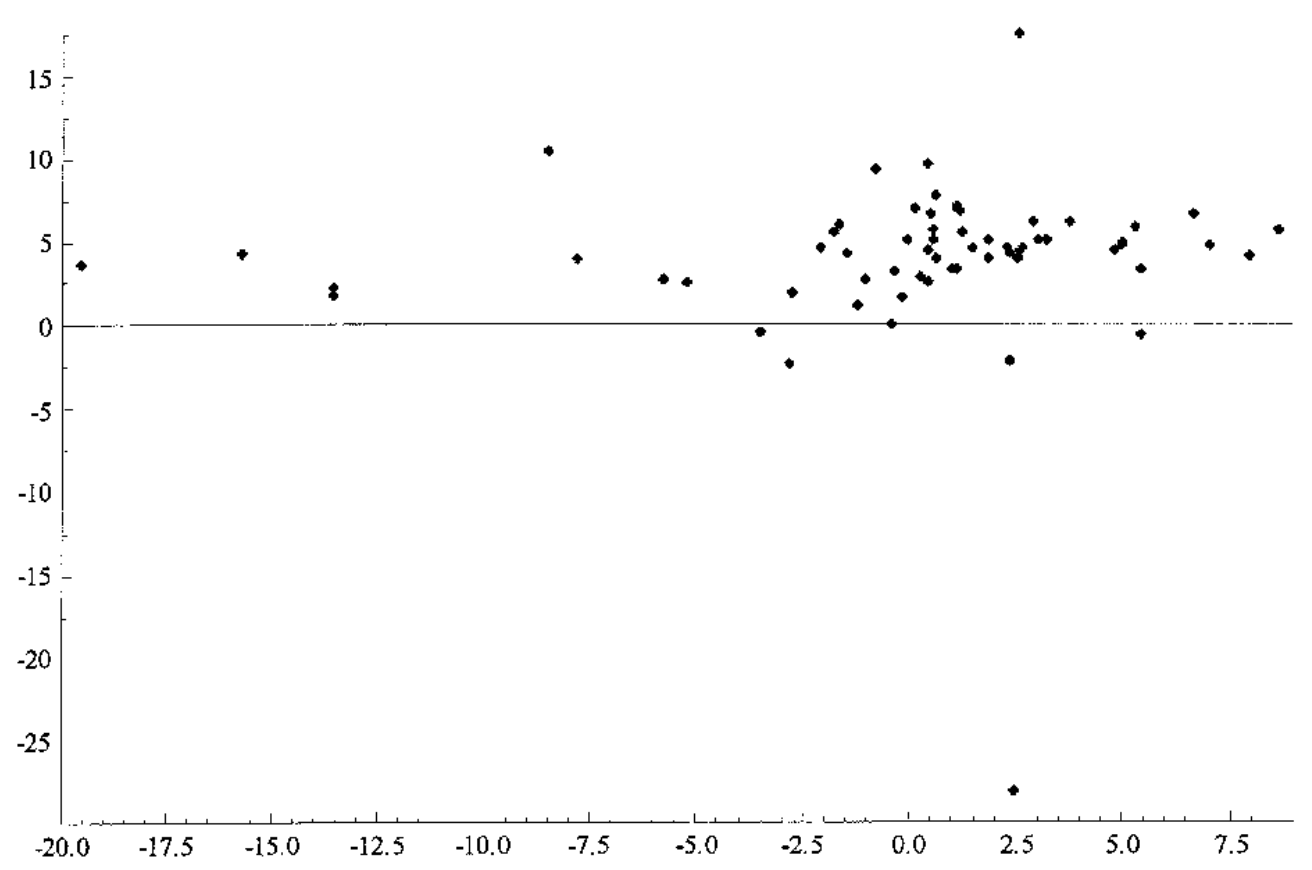


Figure 2. Subsample of Six WAEMU Countries: Instability and Growth

GDP growth and Domestic Instability

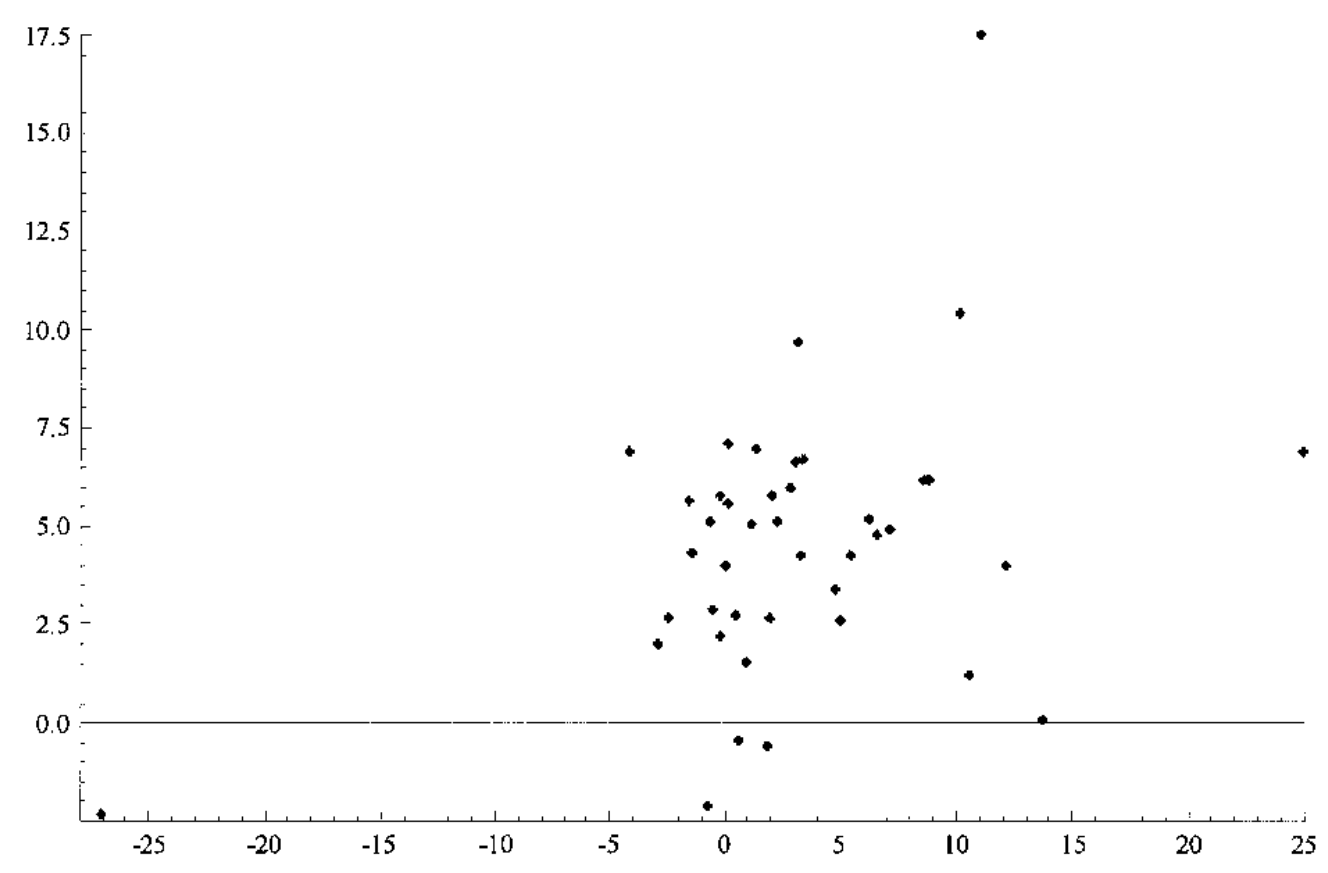

GDP Growth and Regional Instability

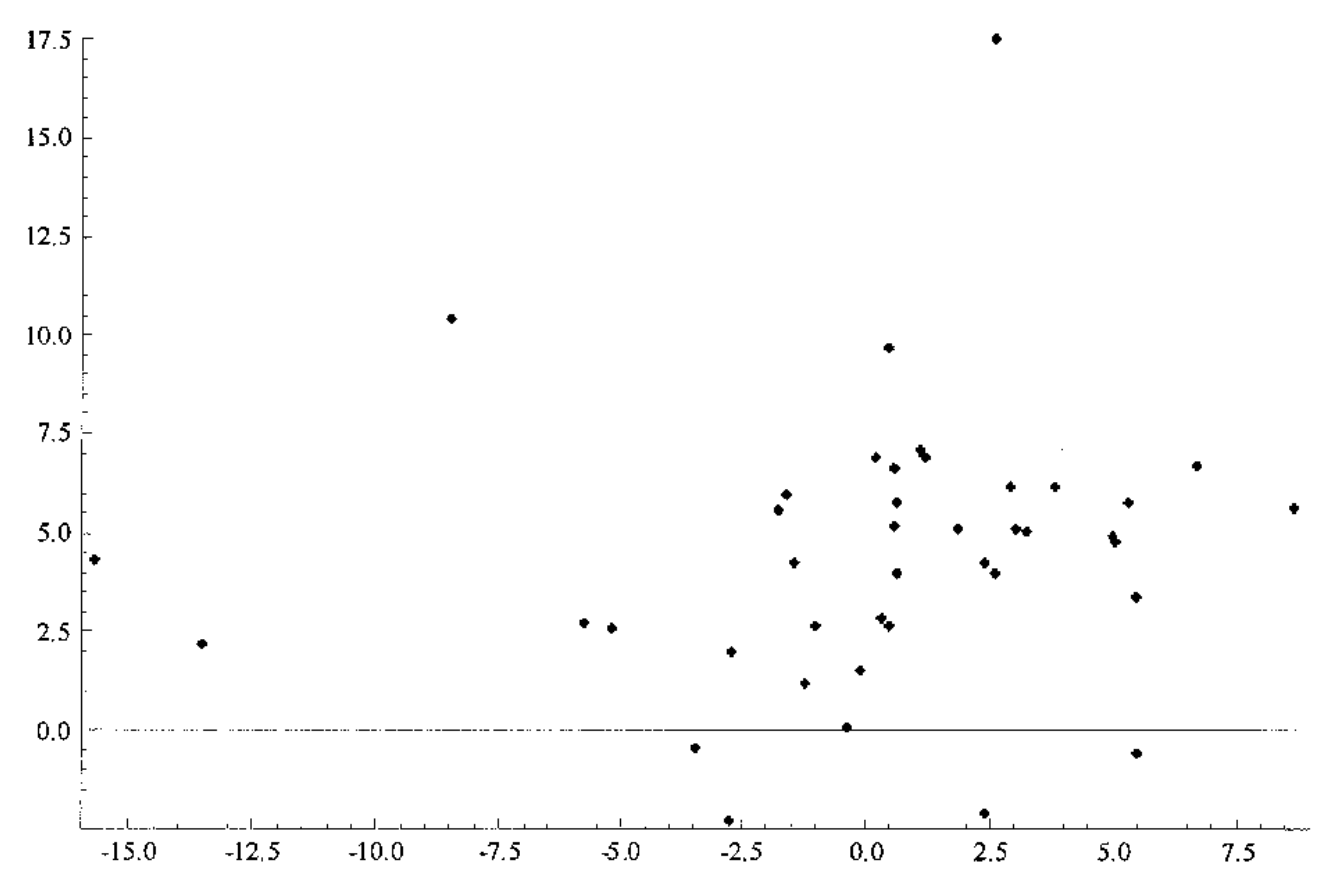


Figure 3. Subsample of Five Countries in Geographical Proximity: Instability and Growth

Top Graph: GDP growth x DII

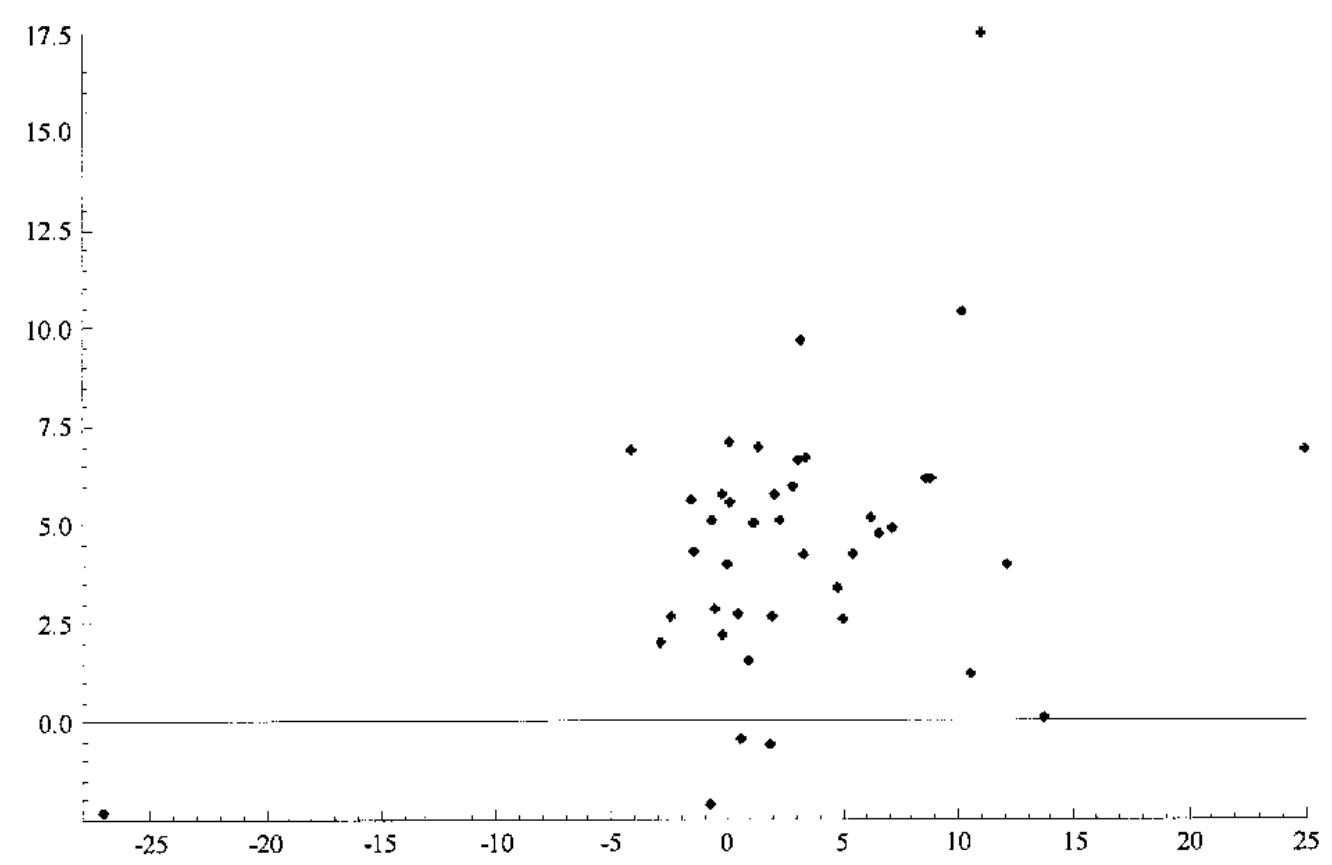

GDP Growth and Regional Instability

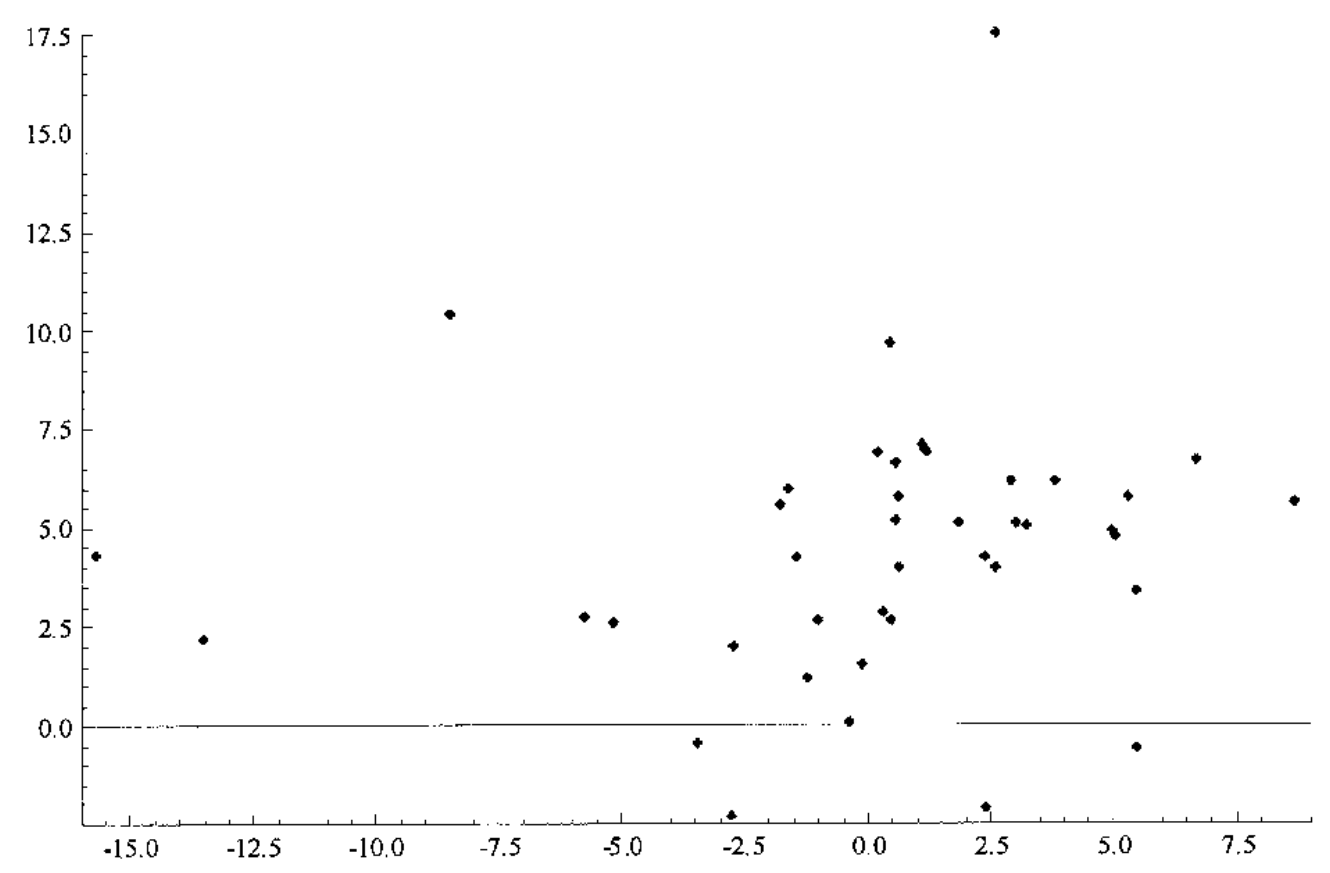


Table 6. Regression Results

(Dependent Variable: GDP Growth)

\begin{tabular}{|c|c|c|c|c|c|c|}
\hline \multirow[b]{2}{*}{ Observations } & \multicolumn{2}{|c|}{ Full Sample } & \multicolumn{2}{|c|}{ Subsample 1 (WAEMU) } & \multicolumn{2}{|c|}{ Subsample 2} \\
\hline & 63 & & 42 & & 35 & 35 \\
\hline Regression & (1) & (2) & (1) & (2) & (1) & (2) \\
\hline$D I I$ & $\begin{array}{r}0.183 \\
(4.66)\end{array}$ & $\begin{array}{r}0.183 \\
(4.65)\end{array}$ & $\begin{array}{r}0.212 \\
(6.45)\end{array}$ & $\begin{array}{l}0.209 \\
(5.45)\end{array}$ & $\begin{array}{l}0.185 \\
(16.6)\end{array}$ & $\begin{array}{l}0.171 \\
(6.70)\end{array}$ \\
\hline$R I I$ & $\begin{array}{r}-0.091 \\
(-0.853)\end{array}$ & $\begin{array}{r}-0.045 \\
(-0.602)\end{array}$ & $\begin{array}{r}0.0034 \\
(0.0212)\end{array}$ & $\begin{array}{r}0.019 \\
(0.206)\end{array}$ & $\begin{array}{r}0.047 \\
(1.02)\end{array}$ & $\begin{array}{c}0.0597 \\
(1.81)^{*}\end{array}$ \\
\hline$T O T$ & $\begin{array}{r}0.035 \\
(0.844)\end{array}$ & $\begin{array}{r}0.037 \\
(0.853)\end{array}$ & $\begin{array}{r}0.05 \\
(0.865)\end{array}$ & $\begin{array}{r}0.049 \\
(0.795)\end{array}$ & $\begin{array}{r}-0.016 \\
(-0.934)\end{array}$ & $\begin{array}{l}-0.023 \\
(-1.58)\end{array}$ \\
\hline Govt Exp. & $\begin{array}{r}1.153 \\
(2.29)\end{array}$ & $\begin{array}{r}1.152 \\
(2.29)\end{array}$ & $\begin{array}{r}0.457 \\
(3.29)\end{array}$ & $\begin{array}{r}0.462 \\
(2.94)\end{array}$ & $\begin{array}{r}0.353 \\
(1.76)\end{array}$ & $\begin{array}{r}0.354 \\
(1.68)\end{array}$ \\
\hline $\begin{array}{l}\text { Devaluation } \\
\text { Dummy }\end{array}$ & $\begin{array}{l}-4.365 \\
(-1.33)\end{array}$ & $\begin{array}{l}-4.342 \\
(-1.35)\end{array}$ & $\begin{array}{l}-2.116 \\
(-1.31)\end{array}$ & $\begin{array}{l}-2.103 \\
(-1.35)\end{array}$ & $\begin{array}{l}-3.807 \\
(-7.53)\end{array}$ & $\begin{array}{l}-3.677 \\
(-9.29)\end{array}$ \\
\hline $\begin{array}{l}\text { Intercept } \\
\text { dummies: }\end{array}$ & & & & & & \\
\hline I 0 & $\begin{array}{l}-22.37 \\
(-2.02)\end{array}$ & $\begin{array}{l}-22.49 \\
(-2.02)\end{array}$ & $\begin{array}{r}-6.79 \\
(-2.14)\end{array}$ & $\begin{array}{r}-6.86 \\
(-1.97)\end{array}$ & $\begin{array}{r}-4.14 \\
(-0.885)\end{array}$ & $\begin{array}{r}-4.03 \\
(-0.82)\end{array}$ \\
\hline I 1 & $\begin{array}{l}-22.85 \\
(-1.93)\end{array}$ & $\begin{array}{l}-22.89 \\
(-1.93)\end{array}$ & $\begin{array}{r}-6.26 \\
(-1.78)\end{array}$ & $\begin{array}{r}-6.39 \\
(-1.61)\end{array}$ & $\begin{array}{r}-3.61 \\
(-0.735)\end{array}$ & $\begin{array}{r}-3.72 \\
(-0.732)\end{array}$ \\
\hline I 2 & $\begin{array}{l}-28.76 \\
(-2.00)\end{array}$ & $\begin{array}{l}-28.96 \\
(-1.99)\end{array}$ & $\begin{array}{r}-6.19 \\
(-1.75)\end{array}$ & $\begin{array}{r}-6.27 \\
(-1.68)\end{array}$ & $\begin{array}{r}-5.95 \\
(-1.02)\end{array}$ & $\begin{array}{r}-5.85 \\
(-0.965)\end{array}$ \\
\hline I 3 & $\begin{array}{l}-15.38 \\
(-1.87)\end{array}$ & $\begin{array}{l}-15.51 \\
(-1.86)\end{array}$ & $\begin{array}{r}-5.18 \\
(-2.63)\end{array}$ & $\begin{array}{r}-5.21 \\
(-2.25)\end{array}$ & $\begin{array}{r}-2.33 \\
(-0.689)\end{array}$ & $\begin{array}{r}-2.23 \\
(-0.628)\end{array}$ \\
\hline I 4 & $\begin{array}{r}-35.9 \\
(-2.28)\end{array}$ & $\begin{array}{l}-35.96 \\
(-2.28)\end{array}$ & $\begin{array}{r}-4.30 \\
(-1.42)\end{array}$ & $\begin{array}{r}-4.42 \\
(-1.32)\end{array}$ & $\begin{array}{r}-3.12 \\
(-0.651)\end{array}$ & $\begin{array}{r}-2.98 \\
(-0.595)\end{array}$ \\
\hline I 5 & $\begin{array}{l}-22.06 \\
(-1.92)\end{array}$ & $\begin{array}{l}-22.25 \\
(-1.92)\end{array}$ & $\begin{array}{r}-4.90 \\
(-1.77)\end{array}$ & $\begin{array}{r}-4.98 \\
(-1.58)\end{array}$ & & \\
\hline I 6 & $\begin{array}{l}-16.05 \\
(-2.12)\end{array}$ & $\begin{array}{l}-16.01 \\
(-2.11)\end{array}$ & & & & \\
\hline I 7 & $\begin{array}{l}-17.89 \\
(-1.85)\end{array}$ & $\begin{array}{l}-18.00 \\
(-1.84)\end{array}$ & & & & \\
\hline I 8 & $\begin{array}{l}-18.87 \\
(-1.91)\end{array}$ & $\begin{array}{l}-18.89 \\
(-1.91)\end{array}$ & & & & \\
\hline$\delta^{2}$ & 20.69 & 20.73 & 10.95 & 10.94 & 1.91 & 1.80 \\
\hline$R^{2}$ & 0.36 & 0.36 & 0.31 & 0.31 & 0.64 & 0.66 \\
\hline
\end{tabular}

Note: $t$ - statistics in parentheses; * denotes significance at 10 percent level.

Regression (1): Côte d'Ivoire domestic instability index in year 2000 unchanged from 1999 level.

Regression (2): Côte d'Ivoire actual index of domestic instability. 
Table 7. Unit Root Tests

\begin{tabular}{|c|c|c|c|c|c|c|}
\hline \multirow[t]{2}{*}{ Variable } & \multirow{2}{*}{$\frac{\text { Full Sample }}{\text { Lag length }}$} & \multirow[b]{2}{*}{$\begin{array}{l}\mathrm{ADF} \\
\text { statistic }\end{array}$} & \multirow{2}{*}{$\begin{array}{l}\text { Subsample1 } \\
\text { Lag length }\end{array}$} & \multirow[b]{2}{*}{$\begin{array}{l}\text { ADF } \\
\text { statistic }\end{array}$} & \multicolumn{2}{|l|}{ Subsample2 } \\
\hline & & & & & Lag length & $\begin{array}{l}\text { ADF } \\
\text { statistic }\end{array}$ \\
\hline \multirow{2}{*}{$\begin{array}{l}\text { GDP } \\
\text { Growth } \\
\text { Rate }\end{array}$} & 1 & $-5.8 * *$ & 1 & $-3.5^{*}$ & 1 & $-4.2 * *$ \\
\hline & 0 & $-7.8 * *$ & 0 & $-4.7^{* *}$ & 0 & $-3.9^{* *}$ \\
\hline \multirow[t]{2}{*}{ Govt Exp. } & 1 & -2.5 & 1 & -1.9 & 1 & -2.1 \\
\hline & 0 & $-3.1^{*}$ & 0 & -2.6 & 0 & -2.5 \\
\hline \multirow[t]{2}{*}{$T O T$} & 1 & $-5.7 * *$ & 1 & $-5.2 * *$ & 1 & $-5.1 * *$ \\
\hline & 0 & $-7.8 * *$ & 0 & $-7.3^{* *}$ & 0 & $-5.4 * *$ \\
\hline \multirow[t]{2}{*}{$D I I$} & 1 & $-4.5 * *$ & 1 & $-3.7 * *$ & 1 & $-3.8^{* *}$ \\
\hline & 0 & $-6.6^{* *}$ & 0 & $-5.5^{* *}$ & 0 & $-5.1^{* *}$ \\
\hline \multirow[t]{2}{*}{$R I I$} & 1 & $-5.9 * *$ & 1 & $-4.6 * *$ & 1 & $-4.2 * *$ \\
\hline & 0 & $-7.0^{* *}$ & 0 & $-6.0^{* *}$ & 0 & $-4.2 * *$ \\
\hline
\end{tabular}

Subsample 1: six WAEMU countries.

Subsample 2: five bordering countries.

* indicates significance at 5 percent level.

** indicates significance at 1 percent level. 
Table 8. Autocorrelation Tests on Data Set with Actual Domestic Instability Indices in Year 2000

\begin{tabular}{llll}
\hline & Full Sample & Subsample 1 & Subsample 2 \\
\hline $\operatorname{AR}(1)$ test $(\mathrm{N}(0,1))$ & $-0.26[0.793]$ & $-1.28[0.202]$ & $1.045[0.296]$ \\
$\mathrm{AR}(2)$ test $(\mathrm{N}(0,1))$ & $-0.78[0.434]$ & $0.6112[0.541]$ & $0.541[0.589]$ \\
\hline
\end{tabular}

$P$-values in parentheses. Subsample 1: six WAEMU countries.

Subsample 2: five bordering countries. 
Table 9. Regression Results (Government Expenditure Variable Differenced)

\begin{tabular}{|c|c|c|c|c|c|c|}
\hline \multicolumn{3}{|c|}{ Full Sample } & \multicolumn{2}{|c|}{ Subsample 1 (WAEMU) } & \multicolumn{2}{|c|}{ Subsample } \\
\hline Observations & 63 & 63 & 42 & 42 & 35 & 35 \\
\hline & (1) & (2) & (1) & (2) & (1) & (2) \\
\hline$\overline{D I I}$ & 0.29 & 0.29 & 0.232 & 0.232 & 0.197 & 0.18 \\
\hline & $(7.61)$ & (6.53) & $(7.49)$ & (7.1) & (7.0) & (3.81) \\
\hline$R I I$ & -0.16 & -0.079 & 0.018 & 0.011 & 0.023 & 0.05 \\
\hline & $(-1.33)$ & $(-1.22)$ & $(0.09)$ & $(0.099)$ & $(0.36)$ & $(2.04)$ \\
\hline TOT & 0.037 & 0.04 & 0.05 & 0.05 & -0.006 & -0.013 \\
\hline & $(1.03)$ & $(0.99)$ & $(0.934)$ & $(0.836)$ & $(-0.45)$ & $(-1.2)$ \\
\hline$\Delta$ Govt Exp. & $\begin{array}{l}0.17 \\
(1.49)\end{array}$ & $\begin{array}{l}0.17 \\
(1.49)\end{array}$ & $\begin{array}{l}-0.014 \\
(-0.18)\end{array}$ & $\begin{array}{l}-0.014 \\
(-0.185)\end{array}$ & $\begin{array}{l}0.0197 \\
(0.584)\end{array}$ & $\begin{array}{l}0.017 \\
(0.705)\end{array}$ \\
\hline $\begin{array}{l}\text { Devaluation } \\
\text { dummy }\end{array}$ & $\begin{array}{l}-1.4 \\
(-0.64)\end{array}$ & $\begin{array}{l}-1.35 \\
(-0.65)\end{array}$ & $\begin{array}{l}-0.92 \\
(-0.4)\end{array}$ & $\begin{array}{l}-0.91 \\
(-3.9)\end{array}$ & $\begin{array}{l}-3.27 \\
(-3.15)\end{array}$ & $\begin{array}{l}-3.06 \\
(-4.49)\end{array}$ \\
\hline Intercept & & & & & & \\
\hline Dummies: & & & & & & \\
\hline I 0 & $\begin{array}{l}3.27 \\
(10.4)\end{array}$ & $\begin{array}{l}3.06 \\
(8.85)\end{array}$ & $\begin{array}{l}3.55 \\
(10.6)\end{array}$ & $\begin{array}{l}3.57 \\
(13.2)\end{array}$ & $\begin{array}{l}3.91 \\
(18.1)\end{array}$ & $\begin{array}{l}4.02 \\
(14.9)\end{array}$ \\
\hline I 1 & $\begin{array}{l}5.97 \\
(6.44)\end{array}$ & $\begin{array}{l}5.88 \\
(7.02)\end{array}$ & $\begin{array}{l}4.67 \\
(5.32)\end{array}$ & $\begin{array}{l}4.7 \\
(5.79)\end{array}$ & $\begin{array}{l}5.05 \\
(13.2)\end{array}$ & $\begin{array}{l}4.92 \\
(19.8)\end{array}$ \\
\hline 12 & $\begin{array}{l}4.81 \\
(13.7)\end{array}$ & $\begin{array}{l}4.45 \\
(32.7)\end{array}$ & $\begin{array}{l}4.41 \\
(6.61)\end{array}$ & $\begin{array}{l}4.46 \\
(8.81)\end{array}$ & $\begin{array}{l}4.27 \\
(29.5)\end{array}$ & $\begin{array}{l}4.35 \\
(96.9)\end{array}$ \\
\hline I 3 & $\begin{array}{l}3.91 \\
(17.9)\end{array}$ & $\begin{array}{l}3.67 \\
(35.4)\end{array}$ & $\begin{array}{l}1.95 \\
(5.96)\end{array}$ & $\begin{array}{l}1.94 \\
(5.27)\end{array}$ & $\begin{array}{l}3.6 \\
(28.7)\end{array}$ & $\begin{array}{l}3.69 \\
(30.4)\end{array}$ \\
\hline I 4 & $\begin{array}{l}0.7 \\
(2.04)\end{array}$ & $\begin{array}{l}0.58 \\
(2.13)\end{array}$ & $\begin{array}{l}4.79 \\
(6.80)\end{array}$ & $\begin{array}{l}4.81 \\
(9.48)\end{array}$ & $\begin{array}{l}5.15 \\
(22.3)\end{array}$ & $\begin{array}{l}5.27 \\
(25.6)\end{array}$ \\
\hline I 5 & $\begin{array}{l}4.75 \\
(7.96)\end{array}$ & $\begin{array}{l}4.42 \\
(8.60)\end{array}$ & $\begin{array}{l}4.28 \\
(6.18)\end{array}$ & $\begin{array}{l}4.28 \\
(6.11)\end{array}$ & & \\
\hline 16 & $\begin{array}{l}1.43 \\
(3.87)\end{array}$ & $\begin{array}{l}1.51 \\
(3.84)\end{array}$ & & & & \\
\hline I 7 & $\begin{array}{l}5.17 \\
(10.4)\end{array}$ & $\begin{array}{l}4.98 \\
(14.7)\end{array}$ & & & & \\
\hline I 8 & $\begin{array}{l}4.82 \\
(7.22)\end{array}$ & $\begin{array}{l}4.77 \\
(7.35)\end{array}$ & & & & \\
\hline$\delta^{2}$ & 22.68 & 22.81 & 11.67 & 11.67 & 2.36 & 2.25 \\
\hline$R^{2}$ & 0.3 & 0.29 & 0.26 & 0.26 & 0.55 & 0.57 \\
\hline
\end{tabular}

Notes: $t$-statistics in parentheses.

Regression (1): Côte d'Ivoire domestic instability index in year 2000 unchanged from 1999 level.

Regression (2): Côte d'Ivoire actual index of domestic instability. 
Table 10. Exports from Côte d'Ivoire to the Region, 1994-2000 (Annual percentage change)

\begin{tabular}{|c|c|c|c|c|c|c|c|c|c|c|}
\hline & 1994 & 1995 & 1996 & 1997 & 1998 & 1999 & 2000 & $\begin{array}{l}\text { Average } \\
1994-98 \\
\end{array}$ & $\begin{array}{c}\text { Average 1999- } \\
2000 \\
\end{array}$ & \\
\hline \multicolumn{11}{|c|}{ Percentage change } \\
\hline Africa & 4.37 & 14.63 & 17.90 & 13.60 & 16.63 & -17.22 & 6.83 & 13.43 & & -5.20 \\
\hline Benin & 71.66 & 32.49 & 5.87 & 25.81 & 2.48 & 2.58 & -19.49 & 27.66 & & -8.46 \\
\hline Burkina & & & & & & & & & & \\
\hline Faso & -4.51 & 12.13 & 7.24 & 22.39 & 27.11 & 18.73 & -30.95 & 12.87 & & -6.11 \\
\hline Ghana & 4.37 & 55.11 & 34.33 & 25.13 & 63.37 & -45.86 & -1.63 & 36.46 & & -23.75 \\
\hline Guinea & -25.35 & 16.58 & 32.14 & -20.20 & -31.01 & 13.20 & 7.34 & -5.57 & & 10.27 \\
\hline $\begin{array}{l}\text { Guinea- } \\
\text { Bissau }\end{array}$ & 82.23 & -60.30 & 126.60 & -71.77 & -60.67 & 306.52 & -59.32 & 3.22 & & 123.60 \\
\hline Liberia & 17.26 & 318.45 & -41.60 & 8.35 & 91.88 & 11.72 & 58.94 & 78.87 & & 35.33 \\
\hline Mali & -2.25 & 40.04 & 21.84 & 9.68 & 5.18 & -4.68 & 2.27 & 14.90 & & -1.21 \\
\hline Niger & -10.33 & 23.78 & 11.28 & 25.83 & 15.94 & 7.12 & -25.58 & 13.30 & & -9.23 \\
\hline Senegal & -13.84 & 4.58 & 23.17 & -14.54 & 0.72 & 44.22 & 117.69 & 0.02 & & 80.96 \\
\hline Togo & 26.66 & 65.82 & 82.74 & -3.62 & -6.18 & 12.61 & 24.14 & 33.08 & & 18.38 \\
\hline
\end{tabular}

Source: IMF, Direction of Trade Statistics. 
Table 11. Imports to Côte d'Ivoire from the Region, 1994-2000

(Annual percentage change)

\begin{tabular}{|c|c|c|c|c|c|c|c|c|c|c|}
\hline & 1994 & 1995 & 1996 & 1997 & 1998 & 1999 & 2000 & $\begin{array}{l}\text { Average } \\
1994-98 \\
\end{array}$ & $\begin{array}{c}\text { Average } \\
1999-2000\end{array}$ & \\
\hline \multicolumn{11}{|c|}{ Percentage change } \\
\hline Africa & -21.65 & 30.34 & 27.89 & -17.24 & -11.07 & 10.23 & 47.06 & 1.65 & & 28.64 \\
\hline Benin & -98.10 & 819.73 & -74.26 & 124.70 & 74.79 & -4.26 & -60.09 & 169.37 & & -32.18 \\
\hline \multicolumn{11}{|l|}{ Burkina } \\
\hline Faso & -61.79 & -3.62 & 8.20 & -66.59 & 86.63 & -21.90 & -2.86 & -7.44 & & -12.38 \\
\hline Ghana & 7.99 & 199.27 & -43.39 & -77.85 & 93.79 & 94.16 & -54.01 & 35.96 & & 20.08 \\
\hline Guinea & -62.24 & 120.56 & 68.64 & 12.37 & 14.92 & 1.36 & 6.47 & 30.85 & & 3.91 \\
\hline $\begin{array}{l}\text { Guinea- } \\
\text { Bissau }\end{array}$ & 79.74 & 30.24 & -69.83 & $100.00^{-}$ & 242.22 & -82.17 & -47.79 & 36.48 & & -64.98 \\
\hline Liberia & $1,583.99$ & 385.55 & -90.66 & -97.20 & $15,234.94$ & 52.49 & 2.84 & 3403.32 & & 27.67 \\
\hline Mali & -73.88 & 40.35 & 45.88 & -32.68 & -34.60 & -51.49 & 243.52 & -10.99 & & 96.01 \\
\hline Niger & -13.01 & -70.30 & -42.06 & 349.46 & -92.09 & 291.90 & 121.37 & 26.40 & & 206.64 \\
\hline Senegal & -23.92 & 45.01 & 15.22 & -12.08 & 36.93 & -23.75 & -21.85 & 12.23 & & -22.80 \\
\hline Togo & -54.50 & 30.83 & 2269.10 & -50.13 & -89.75 & 497.32 & 79.67 & 421.11 & & 288.49 \\
\hline
\end{tabular}


Table 12: Main Destination of Exports from Côte d'Ivoire and Neighboring Countries, 1999-2000

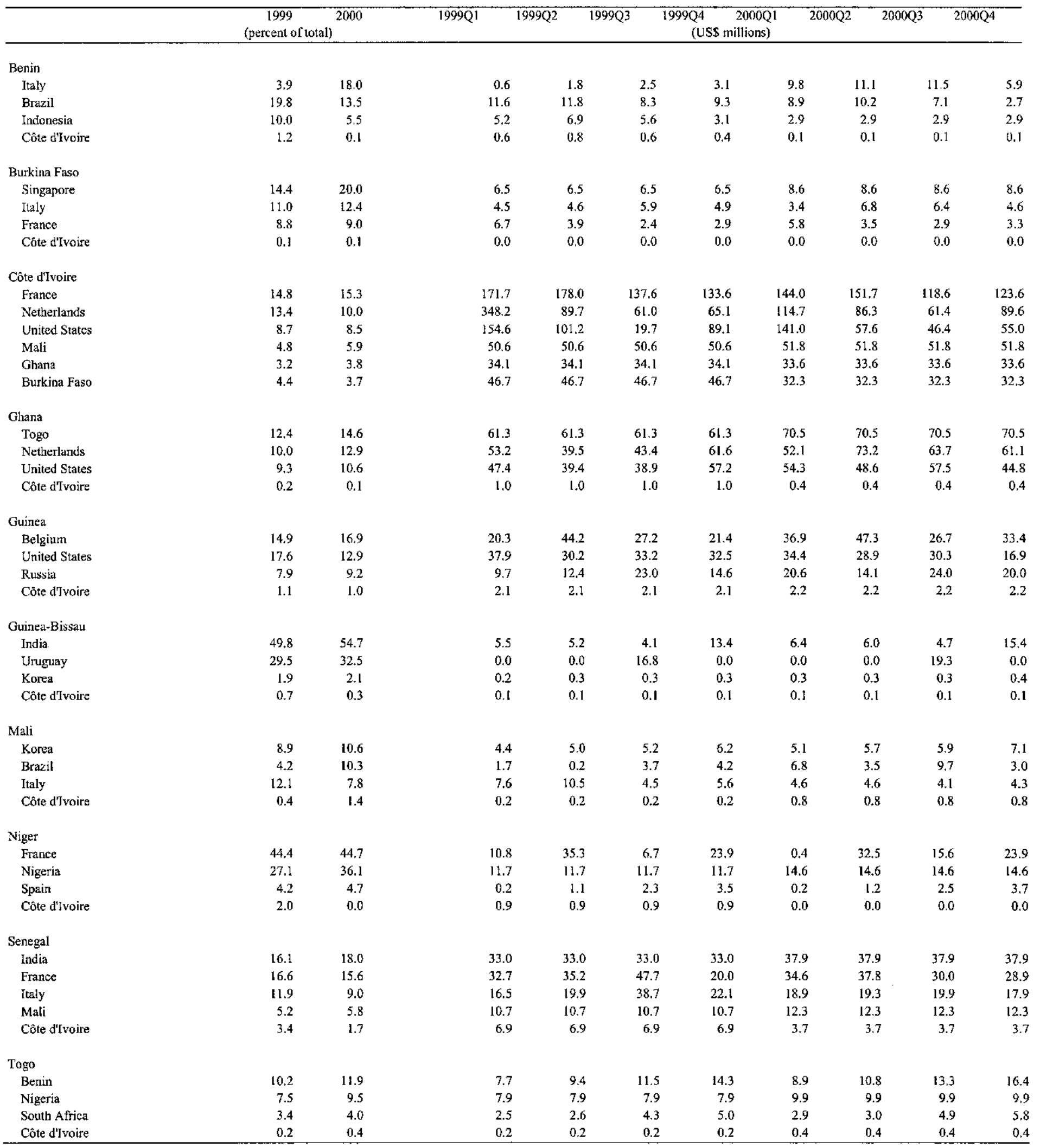

Source: IMF, Direction of Trade Statistics. 
Table 13. Main Origins of Imports to Côte d'Ivoire and Neighboring Countries, 1999-2000

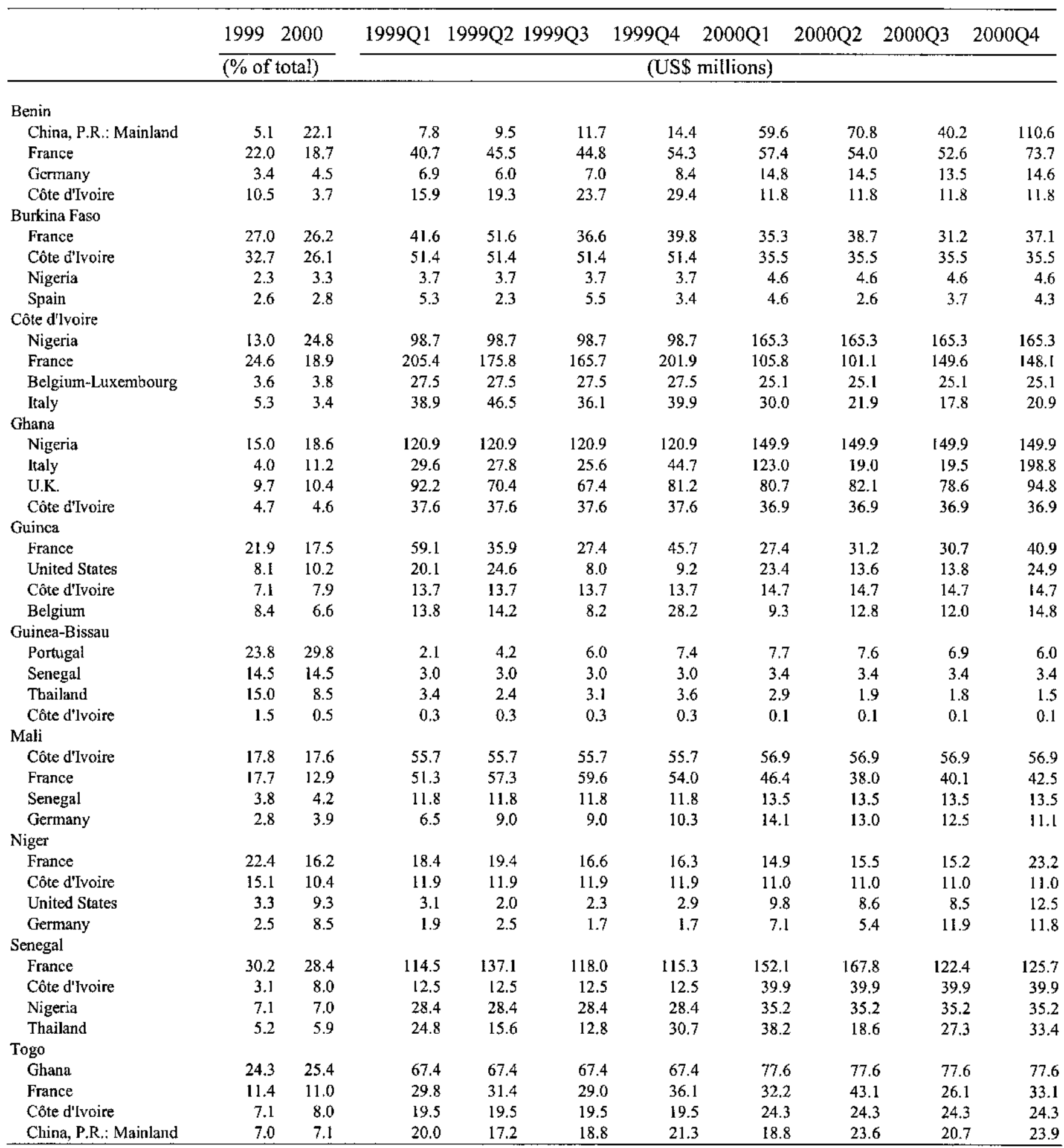

Source: IMF Direction of Trade Statistics. 
Table 14. Volume of Imports and Exports of Goods to Countries in the Region, 1995-2000

(Annual percentage change)

\begin{tabular}{lrrrrrr}
\hline & 1995 & 1996 & 1997 & 1998 & 1999 & 2000 \\
\hline Volume of imports of: & & & & & & \\
& & & & & & \\
Burkina Faso & 36.11 & 12.24 & -1.82 & 37.04 & -9.46 & -14.93 \\
Côte d'Ivoire & 39.77 & 0.81 & 4.84 & 5.00 & 3.66 & -6.01 \\
Mali & 7.84 & 29.09 & 8.45 & 5.19 & 6.17 & -2.33 \\
& & & & & & \\
Benin & 41.94 & 2.27 & 4.44 & 8.51 & 5.88 & 3.70 \\
Ghana & 5.00 & 36.90 & 40.43 & 1.86 & 10.33 & -25.07 \\
Senegal & 5.17 & 1.64 & 1.61 & 15.87 & 10.27 & -2.48 \\
Togo & -2.78 & 2.86 & 5.56 & -2.63 & 2.70 & 18.42
\end{tabular}

Volume of exports

\begin{tabular}{lrrrrrr} 
Burkina Faso & 14.29 & 0.00 & 8.33 & 53.85 & -12.50 & -8.57 \\
Côte d'Ivoire & 7.89 & 31.71 & -11.11 & 4.17 & -2.00 & -18.37 \\
Mali & 15.79 & 2.27 & 48.89 & 0.00 & 17.91 & -3.80 \\
& & & & & & \\
Benin & -4.00 & 20.83 & -17.24 & 16.67 & 14.29 & 9.38 \\
Ghana & 1.42 & 28.67 & 4.89 & 12.44 & -2.76 & 3.32 \\
Senegal & 14.12 & 0.00 & -2.06 & 8.42 & 11.65 & -1.74 \\
Togo & 24.14 & -11.11 & 3.13 & 12.12 & -2.70 & 11.11 \\
\hline
\end{tabular}

Sources: IMF, World Economic Outlook; and country authorities' estimates. 
Table 15. Current Transfers of Countries in the Region, 1994-2000

(In millions of U.S. dollars)

\begin{tabular}{lrrrrrrr}
\hline & 1994 & 1995 & 1996 & 1997 & 1998 & 1999 & 2000 \\
\hline Benin & 50.43 & 68.12 & 67.04 & 76.92 & 71.52 & 74.01 & 76.60 \\
Burkina Faso & 97.99 & 106.12 & 84.03 & 74.50 & 74.91 & 99.87 & 80.40 \\
Côte d'Ivoire & -259.19 & -42.88 & -51.60 & -46.63 & -47.46 & -45.45 & -30.20 \\
Ghana & 271.00 & 263.20 & 276.10 & 400.00 & 453.80 & 472.00 & 495.60 \\
Guinea & -123.91 & -150.26 & -129.49 & -124.92 & -136.68 & -109.41 & -111.83 \\
Guinea-Bissau & 1.22 & 2.70 & 2.00 & 2.00 & 16.10 & 4.57 & 6.00 \\
Mali & 84.83 & 95.77 & 90.14 & 73.00 & 67.80 & 74.37 & 59.33 \\
Niger & -40.89 & -22.64 & -25.41 & -22.32 & -5.76 & -4.88 & -10.73 \\
Senegal & 38.54 & 39.85 & 39.88 & 34.95 & 36.48 & 87.50 & 126.97 \\
Togo & 8.47 & 11.02 & 9.60 & 9.27 & 10.94 & 20.72 & 24.52 \\
\hline
\end{tabular}

Sources: IMF, World Economic Outlook; and country authorities' estimates. 
Table 16. Net Foreign Direct Investment of Countries in Region, 1994-2000 1/

(In millions of U.S. dollars)

\begin{tabular}{lcccccrr}
\hline & 1994 & 1995 & 1996 & 1997 & 1998 & 1999 & 2000 \\
\hline Benin & 7.56 & 4.01 & -6.25 & 18.85 & 18.13 & 31.23 & 23.55 \\
Burkina Faso & 0.00 & 0.00 & 0.00 & 0.00 & 0.00 & 0.00 & 0.00 \\
Côte d'Ivoire & -25.22 & 234.42 & 222.83 & 313.86 & 245.90 & 50.27 & -70.62 \\
Ghana & 30.00 & 35.00 & 20.00 & 36.00 & 45.00 & 45.60 & 59.30 \\
Guinea & 0.01 & 0.01 & 0.01 & 0.01 & 0.01 & 0.01 & 0.01 \\
Guinca-Bissau & 0.00 & 0.00 & 0.00 & 0.00 & 0.00 & 0.00 & 0.00 \\
Mali & 45.00 & 30.10 & 43.33 & 69.73 & 8.98 & 1.30 & 147.88 \\
Niger & -3.24 & 20.64 & 5.47 & -1.55 & -0.34 & 1.79 & 4.43 \\
Senegal & 61.42 & -24.18 & 7.39 & 114.31 & 86.25 & 194.38 & 82.23 \\
Togo & 0.00 & 0.00 & 0.00 & 0.00 & 0.00 & 0.00 & 0.00 \\
\hline
\end{tabular}

Sources: MM, World Economic Outlook; and country authorities' estimates.

1/ Excluding dcbt-creating liabilities. 
Table 17. Index of Domestic Instability in Selected West African Countries $(0=$ worst, $100=$ best $)$

\begin{tabular}{|c|c|c|c|c|c|c|c|c|c|c|}
\hline & Burkina Faso & Cote d'Ivoire & Ghana & Guinea & $\begin{array}{r}\text { Guinea- } \\
\text { Bissau }\end{array}$ & Liberia & Mali & Niger & Senegal & Togo \\
\hline 1994 & 53.08 & 62.08 & 64.50 & 48.00 & 44.00 & 26.50 & 55.08 & 43.00 & 53.08 & 40.00 \\
\hline 1995 & 53.08 & 62.17 & 64.67 & 49.00 & 44.00 & 29.17 & 55.83 & 45.17 & 56.42 & 50.00 \\
\hline 1996 & 54.58 & 59.58 & 64.50 & 48.92 & 43.83 & 31.42 & 57.67 & 47.33 & 57.75 & 51.58 \\
\hline 1997 & 58.17 & 64.83 & 65.08 & 49.67 & 46.17 & 41.25 & 59.67 & 47.58 & 58.42 & 54.42 \\
\hline 1998 & 63.17 & 66.17 & 65.08 & 55.00 & 46.67 & 48.17 & 63.92 & 52.42 & 57.50 & 54.00 \\
\hline 1999 & 63.08 & 66.83 & 64.17 & 56.58 & 49.08 & 44.08 & 65.92 & 53.42 & 57.17 & 52.67 \\
\hline 2000 & 63.00 & 48.75 & 61.00 & 55.25 & 50.25 & 43.75 & 65.00 & 60.75 & 57.25 & 53.00 \\
\hline
\end{tabular}

Source: PRS political risk index, averaged over the year 


\section{REFERENCES}

Ades, Alberto, and Hark B. Chua 1993, "Regional Instability and Economic Growth: Thy Neighbor's Curse," Yale University Economic Growth Center, Discussion Paper No. 704 (New Haven, Connecticut Yale University).

Alesina, Alberto and others 1992, "Political Instability and Economic Growth," NBER Working Paper, No. 4173 (Cambridge, Massachusetts: National Bureau of Economic Research).

Alesina, Alberto, and Roberto Perotti, 1993, "Income Distribution, Political Instability, and Investment," NBER Working Paper No. 4486 (Cambridge, Massachusetts: National Bureau of Economic Research).

Barro, Roberto 1989, "Economic Growth in a Cross Section of Countries," NBER Working Paper, No. 3120 (Cambridge, Massachusetts: National Bureau of Economic Research).

Guillaumont, Patrick, Sylvanie G. Jeanneney, and Brun, Jean-Francois 1999, "How Instability Lowers African Growth," Journal of African Economies, Vol. 8 (March), pp. 87-107.

Masson, Paul, and Catherine Pattillo 2001, "Monetary Union in West Africa: An Agency of Restraint for Fiscal Policies?," IMF Working Paper 01/34 (Washington: International Monctary Fund).

Nixon, Frederick, and Bernard Walters 1999, "The Asian Crisis: Causes and Consequences," The Manchester School, Vol. 67 (No.5), pp. 496-523. 